\title{
Six Times Monthly
}

National Cancer Institute

\section{Source}

National Cancer Institute. Six Times Monthly. NCI Thesaurus. Code C98856.

Six times per month. 